\title{
Diabetes mellitus type 2 from the perspective of ayurveda, a case study
}

\begin{abstract}
Diabetes is a severe metabolic disorder. From a global perspective, it is becoming a growing problem due to the ever-increasing numbers of patients. The WHO estimates the number of people with diabetes around 347 million people with countries such as China, the United States, and India as the countries with the highest number of patients. ${ }^{1}$ Ayurveda treats diabetes with a person-specific combination of cleansing cures, dietary advice, herbs and mental guidance. In this report we study the efficacy of person-specific combination of therapy combined with the herbal supplement Mohana Choorna consisting of 20 different herbs in a case study from a patient with impaired glucose tolerance.
\end{abstract}

Materials and methods: Supply of the herbal formula Mohana Choorna consisting of 21 herbs that act on different layers of the body, dietary advices and lifestyle based on the patients dosha, mental guidance during the first 6weeks of the protocol.

Results: After four weeks of strictly following the Ayurveda protocol the HbA1c levels decreased profoundly. Two years after the start of the Ayurveda protocol T2D is reversed. Five years after this is still the case.

Conclusion: Our findings suggest that Ayurveda treatment with a person-specific combination of cleansing cure, dietary advice, Mohana choorna and mental guidance can reverse $\mathrm{T} 2 \mathrm{D}$.

Keywords: WHO, Ayurveda, obesity, metabolic syndrome, diabetes mellitus, blood, plasma, muscles, bones, marrow, ligaments
Volume 12 Issue 6 - 2019

\author{
Peters CJM,' Mohana Kumari VP,' Peters VM² \\ 'Europa Ayurveda Centrum, The Netherlands \\ ${ }^{2}$ Europa Ayurveda Centrum, Herbal Research Garden, The \\ Netherlands
}

Correspondence: Cornelis Peters, Europa Ayurveda Centrum, dept. Clinic, Witharen, the Netherlands,

Email cornelispeters@gmail.com

Received: July 01, 2019 | Published: November 21, 2019

\section{Introduction}

The Ayurveda describes a set of complex clinical conditions with frequent, abnormal miction, collectively called Prameha, that in many ways correlate with obesity, metabolic syndrome, and diabetes mellitus. Obesity, metabolic syndrome, and diabetes mellitus have in common that they are all three metabolic disorders. In the pathogenesis of Prameha, the role of intermediate metabolites is vital because it is an acquired disease due to incorrect metabolism of nutrients. In Ayurveda, Ama refers to toxic intermediates of digestion and metabolism due to incompletely digested food.

In Ayurveda, diabetes mellitus falls under the Prameha category. Prameha comes from the original word Mih sechane, and that means "water that dilutes everything in the body." It is a disease in which the Doshas are out of balance. Prameha is a collective term of 20 disorders in which the entire urinary system is involved, characterized by excessive urination with abnormal values.

Traditionally, hundreds of herbs are used in Ayurveda. According to ethnobotanical information, there are as many as 800 different plants used in the traditional treatment of diabetes mellitus. ${ }^{2}$ Treating diabetes without adverse side effects remains a significant challenge, and Ayurveda can play an essential role in it. The far-reaching differentiation in primary and secondary Dosha typing in Ayurveda makes it possible to fine-tune the therapy to the person.

\section{Health according to Ayurveda}

It is essential to understand and treat diseases and to know what is meant by health in Ayurveda. By health is meant that body, mind, and soul are in harmony with themselves and with their environment. The person is disease-free and happy with what he or she is doing. That means that the three bio-energies Vata, Pitta and Kapha are in balance, the digestive fire is good, all tissues, organs, and systems function correctly and that the excretion is also trouble-free. On a mental level, people experience a state of well-being with themselves and with the world around them. There is harmony on all levels.

Unhealthy is the opposite of one or more of the above concepts. A person's constitution determines how susceptible that person is to diseases and to which diseases in the first instance. A Vata person is most vulnerable to Vata diseases, a Pitta person to Pitta diseases and a Kapha person to Kapha diseases. After all, often the Dosha who is prominent is also the first to be raised and this can - if he is not corrected in time - give rise to illness. This sentence is not a golden rule, but it is most common.

\section{Four fundamental processes in the development of disease}

Before someone gets sick, many processes have already been disrupted. You can identify four fundamental processes that underlie the onset of illness:

a) Increase of the Doshas - Dosha Utpādaka.

b) The decline of the digestive fire - Agnimandya.

c) Preparation of Ama - undigested products, toxins.

d) The further course of the present disease - Samprāpti.

\section{Disruption of the doshas at prameha}

As a result of the specific Dosha that is disrupted, we distinguish three groups at Prameha, namely Kaphaja Prameha, Pittaja Prameha and Vataja Prameha (Table 1). 
Table I Prameha groups

\begin{tabular}{lll}
\hline Prameha & Sub-types & Stages \\
\hline Kaphaja & 10 & Can be cured \\
Pittaja & 6 & Can kept under control \\
Vataja & 4 & Difficult to treat \\
\hline
\end{tabular}

Prameha is assigned to the different Doshas depending on the stage at which the disruption occurs. Kapha is out of balance in the very first phase. If Kapha "raises," the other Doshas suffer immediately. The increase in Kapha increases the fat content and results in edema formation in the body. At this stage, we speak of Kaphaja Prameha. The first step to disruption has begun. If no steps are taken to address the cause of the interruption, Kapha weakens and Pitta increases. Pitta is the second Dosha that influences the course of the imbalance in the body. Pitta increases and causes a disturbance in the blood. This stage is called Pittaja Prameha. If nothing is done about the cause, the situation continues to deteriorate. Pitta is decreasing, and Vata is going to increase. Due to the pressure of Vata, vital substances end up in the blood and are excreted in the urine. The situation is now rapidly deteriorating, and immediate action is required. The increase of Vata is the stage of Vataja Prameha.

\section{Complications over time}

In the long term, diabetes mellitus can cause all kinds of complications, such as kidney failure, paralysis, and gangrene formation. That is why Ayurveda treats from the first day not only the hyperglycemia but the entire person: physically, mentally, and spiritually. The Ayurvedic anatomy of the coarse-material tissues and the fine-material layers are included in the treatment because all these tissues and layers are affected by this disease. We distinguish the seven body tissues: blood, plasma, muscles, bones, marrow, ligaments, and reproductive tissues. The seven body tissues are our physical body or the food layer.

i. Food layer - Annamaya Kosha.

ii. Energy layer - Pranamaya Kosha.

iii. The mental layer - Manomaya Kosha.

iv. The intellectual layer - Vijnanamaya Kosha.

v. The spiritual layer - Anandamaya Kosha.

\section{Diabetes treatment program from the Europa Ayurveda center}

Over the years, we have developed a treatment program at our center in which we make use of the Prameha classification according to the Doshas and supplemented with the treatment of all Koshas. Upon finding Kaphaja Pramehas, we start with dietary advice and herbal supplements. At Pittaja Pramehas, we also add cleansing cures. When we see the Vataja Pramehas stage, we do the entire program that involves all Koshas.

In the first Kosha, the physical body, we take into account a change in the diet and the prescription of herbs. The precise adjustment depends on the degree of disruption of the relevant Dosha. That is, therefore, different from person to person.
In the second layer, we teach our clients special breathing exercises, so that fresh oxygen is distributed well throughout the body. Every cell in our body needs oxygen, so proper supply and removal is essential. When toxins contaminate the body tissues, we do cleansing cures so that the body can clean at the cellular level. With the third layer, we aim for a change in thinking so that stress is seen in the right perspective. Causes of stress are sorted out individually and tackled in consultation with other healthcare providers. With the fourth layer, we aim for lasting mental change by developing new thinking patterns so that the new lifestyle is experienced as appropriate.

At the fifth layer, we discuss with people the purpose of diseases and what you can learn from them. The sense of being sick. Not the victim position "why does this happen to me," but "how can I best deal with this" and "what does this disease mean in my life" are the starting points for treating this layer.

\section{Case study}

Mr. Jansen visited our practice on 26 May 2010. Mr. Jansen (56years old) is an independent entrepreneur. He had been diagnosed with type 2 diabetes for two years and received medication for this. He used metformin from the very first diagnosis and has been given pioglitazone a few weeks ago. His blood glucose level fluctuated a lot, and he had erectile dysfunction. Erectile dysfunction is known to occur frequently with the combination of metformin with pioglitazone. Besides, he was listless and often tired. Moreover, his weight increased in the last year while, according to him, he did not eat more then he used to eat. On the advice of his brother, he visited our practice, with little enthusiasm, by the way, because he did not put much faith in "herbalists."

After the eightfold Ayurvedic examination - face, tongue, eyes, skin, nails, pulse diagnosis, voice, and urine examination - I found a Pitta as a birth constitution. The acquired constitution or Vikruti indicated Pittaja Prameha, and further urine testing showed this as Kshaara Meha (alkaline urine).

Mr. Jansen had completed a questionnaire beforehand and had done a constitution test so that I already knew quite a bit about him before he came. One of the questions that appear in my history list is the question: "What would you like to achieve in terms of your health and well-being and what would make a difference with your current life if you achieved this?"

The description of health, according to Ayurveda, is a textbook example of how it should be. But living with a chronic illness can also be very useful if you get the most out of your options.

Given his reserved attitude towards alternative medicine, I initially gave him an herbal preparation and clear dietary advices that consist of a list of food products with a plus sign next to it that was good and a minus sign next to it that wasn't good for him.

In the meantime, two years later, Mr. Jansen has gone from two metformin tablets to half a metformin tablet a day and has completely stopped pioglitazone two weeks after the first consultation. The reduction of medicines I informed his treating doctor. His life energy has increased; his company has managed to hold its ground despite the challenging economic times and has even grown in size.

Due to more personal conversations with his partner and the phasing out of his medication and use of the Rasayana herbs, the erection problems are a thing of the past. Rasayana means restoring 
vitality. Rasayana herbs contain a high content of vitamins and trace elements. Mr. Jansen still faithfully goes to his doctor for the diabetes check. His glucose values are within the margins, and his weight has decreased by seven kilos.

He faithfully follows the dietary advice, because he feels excellent about it. It is also not a diet but more an adaptation to the proper combination of food. The combination of proteins/starch, proteins/ sugars, and starch/sugars, and fats/sugars he should avoid as much as possible. Potatoes or cereal products in combination with fruit or tomatoes are not the right choice.

Raisin nuts - the famous student oats - can also better avoided Vegetables together with fruit are also not recommended. Furthermore, cold drinks with meals are strongly discouraged in Ayurveda because it severely disrupts the digestive process. It is, therefore, more a matter of dealing with your food differently. He still uses the Rasayana herbs in a minimal dose. Recently he stopped the metformin and also the Rasayana herbs and only continues with the changing way of dealing with food.

The different way of approaching diseases from Ayurveda has also changed him on a personal level. That proper nutrition has an impact on your body can still be understood, but that your birth constitution determines many choices in your life, was and still is a positive revelation for him. With the support of Ayurveda, he is doing great

In Mohana Choorna, the herbal preparation that is prescribed, some herbs are active in lowering glucose levels; some are active in dilating blood vessels, some in soothing the mind and some Rasayana herbs for overall condition to strengthen. In this formula there are twenty one herbs in total. Four of the twenty one herbs out of this formula are discussed below.

\section{Acorus (Acorus calamus)}

Asaron is a compound that occurs in certain plants and of which tranquility is one. The root of this plant is traditionally used to treat diabetes. Asarone prevented the formation of fat cells in vitro. It gave a significant inhibition of the differentiation of 3T3-L1 pre-adipocytes by suppressing the production of transcription factors that activate adipogenesis. $^{3}$ Besides, asarone reduced cellular fat accumulation. This achieved by lowering the intracellular triglyceride levels, in a dose-dependent manner, and by stimulating (hormone-sensitive) fat breakdown.

\section{Buckwheat (Fagopyrum esculentum)}

The seeds (grains) of the buckwheat are used. Experimental studies (both in laboratory animals and in humans) indicate that buckwheat flour can improve diabetes, obesity, high blood pressure, and increased cholesterol levels. ${ }^{4}$ Buckwheat contains D-chiro-inositol that has been identified as an essential component in the secondary messenger route for insulin signal transduction (insulin second messenger). Type 2 diabetes patients have a deficiency of D-chiro-inositol. ${ }^{5}$ In a test design with rats, D-chiro-inositol has been shown to reduce elevated glucose blood levels. ${ }^{6}$ experimentally. Syringic acid, p-hydroxybenzoic acid, vanilic acid, p-coumaric acid, and proanthocyanidins have been reported to have been observed in the aleurone layer of the bran.?

The protein from buckwheat has a high biological value ${ }^{8}$ and has a close relationship with cholesterol. ${ }^{4}$ This has also been shown in a lower plasma cholesterol value in a study with rats. ${ }^{9}$ Buckwheat contains rutin which is useful in the treatment of hypertension by strengthening capillary blood vessels and which in turn can result in the occurrence of cerebral apoplexy, ${ }^{10}$ as identified in a clinical study. ${ }^{11}$ The seed of buckwheat contains an abundance of vitamins B1 and B2. ${ }^{10}$ The extract from both the skins and the seeds exhibit an antioxidant effect. ${ }^{12}$. Phenolic compounds of the extracts contribute to this activity. ${ }^{13}$ Flavones such as vitexin, isovitexin, orientin, and isoorientin have been demonstrated in the seedlings. ${ }^{14}$ The flavonols such as rutin, hyperin, quercitrin, and quercetin can be isolated from the immature seeds. ${ }^{15}$

\section{Coriander (Coriandrum sativum)}

The seeds of coriander are used in Mohana Choorna. Inclusion of dried and ground coriander seeds in the diet has shown a reduction in blood sugar levels in healthy rats fed a high cholesterol diet ${ }^{18}$ and diabetic mice induced in streptozotocin. ${ }^{16}$ Further research in muscle and liver tissue showed that hypoglycemic effects could be explained by increased glycogen formation, both in the liver ${ }^{18}$ and in muscles, ${ }^{16}$ reduced hepatic gluconeogenesis and increased hepatic glycolysis. ${ }^{18}$

Incubation of clonal $\beta$ cells with an aqueous coriander extract resulted in increased insulin secretion. ${ }^{16}$ This effect was also observed in another study in which peritoneal administration of an ethanol extract coriander in streptozotocin-induced diabetic rats resulted in a lowered blood sugar level and an increased insulin release of the cells. ${ }^{21}$

In addition to these effects on blood glucose, coriander seed has also shown that it can influence the plasma lipid profile. A study in rats - fed a high-fat diet with extra cholesterol added - found that adding ground coriander seed to the diet significantly reduced the level of serum triglyceride and serum LDL and VLDL cholesterol while increasing HDL cholesterol. ${ }^{17}$.

The same effect was observed in another study after incorporating coriander seed oil in the diet of rats fed a cholesterol diet. ${ }^{19}$ Furthermore, it was found that ethanol extract from coriander seed has an antioxidant effect and a viability study of clonal -cells showed that an aqueous extract of coriander is not toxic for these cells. ${ }^{20}$

\section{Bitter melon (Momordica charantia)}

The fruit is used in Mohana Choorna. A scientific study conducted on a mouse model has shown that bitter melon increases insulin sensitivity and therefore lowers blood glucose. ${ }^{22}$ Bitter melon can be useful in people with slow digestion, dyspepsia, and constipation. It contains four promising bioactive compounds that activate the enzyme AMP-activated protein kinase (AMPK), which plays a crucial central role in, among other things, regulating energy metabolism and glucose uptake. ${ }^{23}$ AMPK also increases insulin sensitivity and stimulates mitochondria activity. ${ }^{24}$ These are processes that are disrupted in patients with diabetes.

\section{Conclusion}

Our findings suggest that Ayurveda treatment with a personspecific combination of cleansing cure, dietary advice, Mohana choorna and mental guidance can reverse T2D.

\section{Author information}

Cornelis Peters studied pharmacology and physiology at the University of Applied Science, Utrecht, in the Netherland and 
became a research fellow working in different leading hospitals in the Netherlands. Among them the famous Netherlands Cancer Institute, Antony van Leeuwenhoek. During a sabbatical in India, he came across Ayurveda and decided to study this traditional medicine. Back in the Netherlands, he founded Europa Ayurveda Centrum together with Dr. V.P. Mohana Kumari and Vighnesh M. Peters. Together they form the inspirational driving force behind this institute. Europa Ayurveda Centrum (EAC) is an agricultural estate with treatment and research facilities. The center is actively involved in research projects with Ayurveda medicinal plants that they cultivate in 10 ha of land belonging to the center.

\section{Acknowledgments}

None

\section{Conflicts of interest}

Author declares there are no conflicts of interest.

\section{References}

1. World Health Organization. Factsheet Diabetes. Geneva: World Health Organization.

2. Gulati V, Harding IH, Palombo EA. Enzyme inhibitory and antioxidant activities of traditional medicinal plants: potential application in the management of hyperglycemia. BMC Complement Altern Med. 2012;12:77.

3. Lee SH, Kim KY, Ryu SY, et al. Asarone inhibits adipogenesis and stimulates lipolysis in 3T3-L1 adipocytes. Cell Mol Biol (Noisy-legrand). 2010;24(Suppl 56):OL1215-22.

4. Li SQ, Zhang QH. Advances in the development of functional foods from buckwheat. Crit Rev Food Sci Nutr. 2001;41(6):451-464.

5. Kawa JM, Taylor CG, Przybylski R. Buckwheat concentrate reduces serum glucose in streptozotocin-diabetic rats. J Agric Food Chem. 2003;51(25):7287-7291.

6. Asplin I, Galasko G, Larner J. chiro-Inositol deficiency and insulin resistance: a comparison of the chiro-inositol- and the myo-inositolcontaining insulin mediators isolated from urine, hemodialysate, and muscle of control and type II diabetic subjects. Proc Natl Acad Sci USA. 1993;90(13):5924-5928.

7. Durkee AB. Polyphenols of the bran-aleurone fraction of buckwheat seed (Fagopyrum sagitatum, Gilib). J Agric Food Chem. 1977;25(2):286287.

8. Sure B. Nutritive value of proteins in buckwheat and their role as supplements to proteins in cereal grains. J Agric Food Chem. 1955;3(9):793-795.

9. Tomotake H, Shimaoka I, Kayashita J, et al. Stronger suppression of plasma cholesterol and enhancement of the fecal excretion of steroids by a buckwheat protein product than by a soy protein isolate in rats fed on a cholesterol-free diet. Biosci Biotechnol Biochem. 2001:65(6):14121414 .
10. Watanabe M. Catechins as Antioxidants from Buckwheat (Fagopyrum esculentum Moench) Groats. J Agr Food Chem. 6(3):839-845.

11. Ihme N, Kiesewetter H, Jung F, et al. Leg edema protection from a buckwheat herb tea in patients with chronic venous insufficiency: a single-center, randomized, double-blind, placebo-controlled clinical trial. Eur J Clin Pharmacol. 1996;50(6):443-447.

12. Watanabe M, Sato A, Osawa R, et al.. Antioxidative activity of Buckwheat seed extracts and its rapid estimate for evaluation of breeding materials. J Jpn Soc Food Sci Technol. 1995:42:649-655.

13. Watanabe M, Ohshita Y, Tsushida T. Antioxidant compounds from Buckwheat hulls. J Agric Food Chem. 1997:45(4):1039-1044.

14. Margna UV, Margna ER. Differential nature of quantitative shifts in flavonoid accumulation in buckwheat seedlings of different ages. Soviet Plant Physiol. 1982;29:223-230.

15. Sato H, Sakamura S. Isolation and identification of flavonoids in immature buckwheat seed Agric. Chem Soc Jpn. 1975;49:53-55.

16. Gray AM, Flatt PR. Insulin-releasing and insulin-like activity of the traditional anti-diabetic plant Coriandrum sativum (coriander). $\mathrm{Br} J$ Nutr. 1999;81(3):203-209.

17. Chithra V1, Leelamma S. Hypolipidemic effect of coriander seeds (Coriandrum sativum): mechanism of action. Plant Foods Hum Nutr. 1997;51(2):167-172.

18. Chithra V, Leelamma S. Coriandrum sativum - mechanism of hypoglycemic action. Food Chem. 1999;67(3):229-231.

19. Ramadan MF, Amer MMA, Awad AE. Coriander seed oil improves plasma lipid profile in rats fed a diet containing cholesterol. Eur Food Res Technol. 2008;227(4):1173-1182.

20. Wangesteen H, Samuelsen AB, and Malterud KE. Antioxidant activity in extracts from coriander. Food Chem. 2004;88(2):293-297.

21. Eidi M, Eidi A, Saeidi A, et al. Effect of coriander seed ethanol extract on insulin release from pancreatic beta cells in streptozotocin-induced diabetic rats. Phytother Res. 2009;23(3):404-406.

22. Virdi J, Sivakami S, Shahani S, et al. Antihyperglycemic effects of three extracts from Momordica charantia. J Ethnopharmacol. 2003;88(1):107111.

23. Tan MJ, Ye JM, Turner N, et al. Antidiabetic activities of triterpenoids isolated from bitter melon associated with activation of the AMPK pathway. Chem Biol. 2008;15(3):263-273.

24. Chaturvedi P. Antidiabetic potentials of Momordica charantia: multiple mechanisms behind the effects. J Med Food. 2012;15(2):101-107. 